ECOLOGICA, Vol. 28, No 102 (2021), 283-292

https://doi.org/10.18485/ecologica.2021.28.102.21

Originalni naučni rad

UDC: 677.02:[616.98:578.834]

\title{
Održivost modne industrije u vreme pandemije Covid-19
}

\section{Sustainability of the fashion industry at the time of the Covid-19 pandemic}

\author{
Ljubica Kovačevići ${ }^{*}$, Ljiljana Arsić \\ 1,2Univerzitet u Prištini sa privremenim sedištem u Kosovskoj Mitrovici, Ekonomski fakultet, Kolašinska \\ 156, 38220 Kosovska Mitrovica / \\ University of Priština in Kosovska Mitrovica, Faculty of Economics, Kolašinska 156, 38220 Kosovska Mitrovica \\ *Autor za prepisku / Corresponding author
}

Rad primljen / Received: 17.12.2020, Rad prihvaćen / Accepted: 19.05.2021.

\begin{abstract}
Sažetak: U modnom smislu, na planeti ograničenih resursa evidentna je neodrživost trenutnog linearnog modela sa duboko ukorenjenom praksom brze proizvodnje, potrošnje i odlaganja odevnih predmeta. Multidimenzionalni trend koji je danas zavladao modnom industrijom, podstakao je autore da se bave ovim fenomenom. Intencija autora je da u ovom radu prouče i analiziraju stanje modne industrije koja prožima sve aspekte ljudskog društva. U tom kontekstu, rad ima za cilj da istraži na koji način primena cirkularnog modela u modnoj industriji može da doprinese postizanju ciljeva održivog razvoja. Posmatrano sa ekološkog, ekonomskog i socijalnog aspekta negativni uticaji linearnog modela modne industrije postaju sve transparentniji. Tranzicija ka cirkularnom modelu modne industrije podrazumeva prelazak na potpuno novi, održivi pristup, koji zahteva snažnu sistemsku posvećenost svih učesnika na tržištu. Dostupni nalazi istraživanja na ovu temu, omogućili su autorima da analiziraju ulogu i odnos potrošača prema modi. Demistifikovanjem potrošača, kao donosioca odluka u procesu kupovine, korišćenja i odlaganja odevnih predmeta, ukazuje da su oni od krucijalne važnosti u tranziciji od linearne ka cirkularnoj modnoj industriji. $U$ vreme pandemije nezapamćenih razmera, izazvane virusom COVID-19, poseban izazov obezbeđenja održivosti modne industrije predstavlja ukazivanje na značaj i neminovnovnost njenog reformisanja.
\end{abstract}

Ključne reči: cirkularna ekonomija, održivi razvoj, modna industrija, COVID-19.

\begin{abstract}
In terms of fashion, the unsustainability of the current linear model is evident on the planet of limited resources with a deep-rooted practice of rapid production, consumption, and disposal of clothing. A multidimensional trend that dominates the fashion industry today, encourages authors to deal with this phenomenon. In this paper, the intention of the author is to study and analyze the state of the fashion industry that permeates all aspects of human society. In this context, the paper aims to investigate how the application of the circular model in the fashion industry can contribute to achieving the goals of sustainable development. Observed from the ecological, economic and social aspect, the negative influences of the linear model of the fashion industry are becoming more and more transparent. The transition to a circular model of the fashion industry implies a transition to a completely new, sustainable approach, which requires a strong systematic commitment of all market participants. The available research findings on this topic enabled the authors to analyze the role and attitude of consumers towards fashion. Demystifying consumers, as decision bearers in the process of purchasing, using and disposing of clothing, indicates that they are crucial in the transition from the linear to the circular fashion industry. In the time of pandemic of unprecedented proportions, caused by the COVID-19 virus, a special challenge of ensuring the sustainability of the fashion industry is to point out the importance and inevitability of its reform.
\end{abstract}

Keywords: circular economy, sustainable development, fashion industry, COVID-19.

\footnotetext{
${ }^{1}$ orcid.org/0000-0002-7663-7126, e-mail: Ijubica.kovacevic@pr.ac.rs

${ }^{2}$ orcid.org/0000-0002-3582-8161, e-mail: Ijiljana.arsic@pr.ac.rs
} 


\section{UVOD / INTRODUCTION}

Digitalna tehnologija i savremeni stil života modernog potrošača sa sobom su doneli fenomen brze mode. Permanentna promena trendova, kraći životni vek i niže cene proizvoda proistekli iz kulture „kupi, obuci i odbaci“, učinili su da modna industrija vremenom postane jedna od najtraženijih industrija roba široke potrošnje. Primena linearnog modela $u$ modnoj industriji, odnosno, brz dizajn i izrada, potrošnja i odlaganje odevnih predmeta, iniciraju i brzo stvaranje profita.

Modna industrija se prema brojnim saznanjima danas svrstava u kategoriju najvećih zagađivača na svetu. Pogubne posledice koje brza moda ima na životnu sredinu, klimu i društvo, nastale su usled nekontrolisanog trošenja, rasipanja i zagađivanja neobnovljivih resursa. $U$ cilju smanjenja tih posledica, neophodno je da modna industrija bude deo cirkularne ekonomije, gde će kao takva imati sposobnost da produži životni vek odevnih predmeta, zadržavajući resurse u zatvorenom krugu. Cirkularna modna industrija realizacijom ciljeva održivog razvoja nastoji da poveća reciklažu i ponovnu upotrebu tekstila, te na taj način proizvodnju devičanskih tekstilnih vlakana, stvaranje zagađenja i otpada svede na minimum.

U novije vreme, potreba da se smanji uticaj štetnosti modne industrije na životnu sredinu još više dobija na značaju. Pandemija, nezapamćenih razmera, izazvana virusom COVID-19 u trenutku je transformisala čitav svet. Savremenom društvu ovo je još jedna u nizu opomena da čovek ima neograničene potrebe, a planeta ograničeni kapacitet da ih zadovolji. Podvlačenjem jasne linije sveopštih odnosa između čoveka i prirode, savremeno potrošačko društvo je iz stanja da prati i odobrava brzu smenu modnih trendova, odjednom svoja interesovanja svelo na zadovoljenje osnovnih egzistencijalnih potreba.

Smatra se, da modna industrija još uvek nije dovoljno ozbiljno uzela u obzir svoju ekološku odgovornost (McKinsey \& Company, 2020), kao i da vodeći brendovi brze mode na ovom polju pokazuju skromni napredak. Uzevši u obzir multidimenzionalni trend koji danas utiče na modnu industriju, ovaj rad posebnu pažnju posvećuje uticaju modne industrije na životnu sredinu, zatim i analizi odlučujućih faktora neophodnih za tranziciju od linearnog ka cirkularnom modelu. U skladu sa ovim razmatranjima, rad ima za cilj da istraži na koji način primena cirkularnog modela u modnoj industriji može da doprinese postizanju ciljeva održivog razvoja. Dalje, analizom uloge i odnosa potrošača prema modi, autori nastoje da demistifikuju potrošače kao donosioce odluka u procesu kupovine, korišćenja i odlaganja odevnih predmeta.

\section{UTICAJ MODNE INDUSTRIJE NA ŽIVOTNU SREDINU / \\ THE IMPACT OF THE FASHION INDUSTRY ON THE ENVIRONMENT}

Prvobitno, ljudi su odevne predmete kupovali samo onda kada su im bili neophodni, i nosili ih sve dok su mogli da im koriste u svrhu zaštite i utopljavanja. Nakon toga, postali su potrošači koji kroz odevne predmete koje nose kreiraju svoj identitet i društveni status. Dramatična promena u potrošnji i složeniji odnos koji su potrošači razvili prema odevnim predmetima, doveli su do toga da ljudi svaki odevni predmet nose samo nekoliko puta. Procenjeno je da se $80 \%$ svih proizvoda pretvara u „otpad“ i baca u roku od prvih šest meseci od obavljene kupovine (BakerBrown, 2017, 11).

Promenu u željama, ali ne i stvarnim potrebama potrošača, iskoristila je modna industrija. Poslednjih petnaest godina proizvodnja odevnih predmeta se skoro pa udvostručila (Ellen McArthur Foundation, 2017). Svake godine širom sveta proda se 150 miliona tona odevnih predmeta, od čega veći deo završi na deponijama ili se spaljuje, sve to doprinosi trošenju dragocenih resursa i nanosi štetu životnoj sredini (https://www.ico-spirit.com/en/). Procena je da će se otpad iz modne industrije povećati za $60 \%$ u periodu od 2015. do 2030. godine, što će globalno dovesti do 148 miliona tona otpada (GFA and BCG, 2017). U cilju zaštite životne sredine, nužno je u procesu proizvodnje minimizirati otpad (umanjiti potrošnju primarnih sirovina), maksimizirati ponovnu upotrebu i reciklažu otpada, odnosno unapređivati rad službi koje su zadužene za tretman otpada (Ljubojević \& Maksimović Sekulić, 2018, 280).

Modna industrija danas je sve više povezana sa tehnološkim i digitalnim svetom. Sve veća zastupljenost digitalnih platformi i digitalnog marketinga na modnom tržištu pruža mogućnost modnim brendovima da angažuju potrošače i putem virtuelne stvarnosti (Gazzola et al., 2020). Svakodnevna ponuda najrazličitijih odevnih predmeta u digitalnom svetu učinila je da današnji potrošači mnogo brže dobijaju šta žele, kada žele i gde žele. U godinama koje dolaze moguće je povećanje potrošnje proizvoda brze mode, koje je u uzročnoj relaciji sa stalnim porastom globalne populacije i srednje klase. $U$ tom smislu i ne čudi što su mnogi brendovi, zarad opstanka, podlegli izazovima brzo rastućeg modnog tržišta, i u deo svog obaveznog strateškog plana uvrstili ulaganja u tehnološke i digitalne sisteme. Imajući u vidu napred navedeno, možemo reći da su neodvojive determinante brze mode: veći broj modnih sezona, niži troškovi materijala i radne snage, niže cene i kraći životni vek proizvoda, brže vreme isporuke i stvaranje velike količine odevnog otpada. 
Decenije isprepletanih trendova učinile su da modna industrija bude u permanentnom ekonomskom rastu koji zahteva velike količine resursa u svim fazama životnog ciklusa odevnih predmeta, uključujući njihovu proizvodnju, potrošnju i odlaganje. Procenjuje sa da polja pamuka pokrivaju 2,4\% kompletnih svetskih useva (Gam et al., 2010), a godišnja proizvodnja pamuka zahteva $10 \%$ upotrebe svih sintetičkih pesticida u svetu (Gam et al., 2010; Hiller \& Kozar, 2012), i skoro $25 \%$ insekticida (Fletcher, 2014). Prilikom pranja mnogi odevni predmeti oslobađaju plastična mikrovlakna, koja kao takva u fazi potrošnje doprinose zagađenju okeana, te na godišnjem nivou njihov iznos približno dostiže 0,5 miliona tona štetnih materija (Ellen McArthur Foundation, 2017). Pored toga, sve veće količine tekstila koje se proizvode, kupuju i odlažu na deponije, stvaraju specifične probleme, jer se sintetički proizvodi ne razlažu, a vunena odeća tokom razgradnje proizvodi metan i doprinosi globalnom zagrevanju (Grębosz-Krawczyk \& Siuda, 2019, 394). Stoga i ne čudi podatak da odeća, obuća i tekstil za domaćinstvo zauzimaju četvrto mesto u korišćenju resursa vode (odmah nakon hrane, smeštaja i transporta), drugo mesto u korišćenju zemljišta i peto po količini emitovanja gasova sa efektom staklene bašte (NCEAP, 2020).

Ukoliko u obzir uzmemo činjenicu da u krajnju cenu odevnih predmeta nisu uračunati troškovi stvarne vrednosti prirodnih resursa koje angažuje modna industrija, poput čistog zemljišta i vode, vazduha i energije, dolazimo do toga da je vrednost angažovanih resursa nenadoknadiva. Proizvodni i potrošački modeli, koji se primenjuju širom sveta sve više ugrožavaju same osnove na kojima počiva i od kojih zavisi svakodnevni život kako sadašnjih, tako i generacija koje tek dolaze (Janković \& Jović Bogdanović, 2018, 221).

Usled zagađenja nastalih u procesima pribavljanja resursa i stvaranja otpada, pitanja ekološke održivosti modne industrije postaju sve značajnija. Procenjuje se da se manje od $1 \%$ tekstila u svetu reciklira u novi tekstil (Ellen McArthur Foundation, 2017). Ukoliko se sveukupan trend u modnoj industriji nastavi i ubuduće, planeta će na kraju propasti (Svensson, 2016).

\section{TRANZICIJA OD LINEARNE KA CIRKULARNOJ MODNOJ INDUSTRIJI / \\ TRANSITION FROM LINEAR TO CIRCULAR FASHION INDUSTRY}

Značaj tranzicije od linearne ka cirkularnoj modnoj industriji prepoznat je na svim nivoima, počevši od globalnog, regionalnog, pa sve do nacionalnog. Tokom poslednjih nekoliko godina postalo je jasno da su ograničenja linearnog modela (uzmi, napravi, upotrebi, baci) sve veća, i da se njegova primena u osnovi modnog sektora bliži kraju (Koszewska et al., 2020). Ograničeni resursi i sve veća potražnja za odevnim predmetima u trendu, čine trenutni linearni model neodrživim. Rousso (2012) navodi da su moda i održivost dva naizgled kontradiktorna koncepta, jer se moda uvek razvija i menja, dok se održivost fokusira na očuvanje. Alternativa, u ovoj naizgled bezizlaznoj situaciji, jeste cirkularni model modne industrije koji pruža maksimalnu korisnost $\mathrm{i}$ isključuje mogućnost stvaranja otpada.

Prelazak sa linearnog na cirkularni model u modnoj industriji zahteva znanje, svest i angažovanje svih učesnika na tržištu: proizvođača, dizajnera tehnologije i proizvoda i potrošača (Koszewska et al., $2020,327)$. Rezultat toga su odevni predmeti dizajnirani od materijala koji može da se reciklira nekoliko krugova, podržavajući svaki aspekt cirkularnog modela. Dakle, odevni predmeti visokog kvaliteta i trajnosti predstavljaju neophodan preduslov održivosti modnog sektora (Ellen McArthur Foundation, 2017).

Na slici 1 predstavljen je dobar model za modni sektor, koji ukazuje na sistem od četiri nivoa:

- prvi nivo, dizajniranje za dugotrajnost, u fokus stavlja potrošača, cilj mu je produžiti fazu upotrebe proizvoda,

- drugi nivo, dizajniranje za uslugu, usmerava se na nove poslovne modele za proširenje ili intenziviranje upotrebe proizvoda brendova i kompanija,

- $\quad$ treći nivo, dizajn za ponovnu upotrebu, uključuje izazove sa kojima se proizvođači susreću prilikom uvođenja novih modela, koji za cilj imaju da produže vreme upotrebe proizvoda tako što ga vraćaju u prvobitno stanje,

- četvrti nivo, dizajn za oporavak materijala, bazira se na reciklaži materijala, koristeći otpad za proizvodnju novih vlakana i prediva (RSA, 2016).

Model od četiri nivoa pored toga što angažuje ključne učesnike na tržištu koji su potrebni za sprovođenje transformacije ka cirkularnosti, upućuje i na stvaranje međusobne saradnje između dizajnera, istraživača, industrija, kompanija, korisnika i kreatora politike (RSA, 2016). Dakle, postizanje cirkularnog modela zahteva ciklične i regenerativne ekološke inovacije u načinu na koji društvo donosi zakone, proizvodi i troši (Machado et al., 2019, 383).

U decembru 2019. godine Evropska komisija predstavila je Zeleni dogovor, na osnovu koga je u martu 2020. godine usvojila Akcioni plan za cirkularnu ekonomiju. To su ujedno i poslednja dva dokumenta evropske agende za održivi razvoj. Akcioni plan se posebno fokusira na visoko rizične sektore, među kojima su tekstil i odeća, koji su veliki resursni 
potrošači i čija je potreba za prelazak na cirkularni model na veoma visokom nivou. Komisija u skladu sa izazovima sa kojima se susreće predlaže sveobuhvatnu strategiju Evropske unije za tekstilni sektor. Pomenuta strategija za cilj će imati jačanje industrij- ske konkurentnosti i inovacija, jačanje tržišta Evropske unije za održivi i kružni tekstil, uključujući tržište ponovne upotrebe tekstila, bavljenje brzom modom i vođenje novih poslovnih modela (NCEAP, 2020).

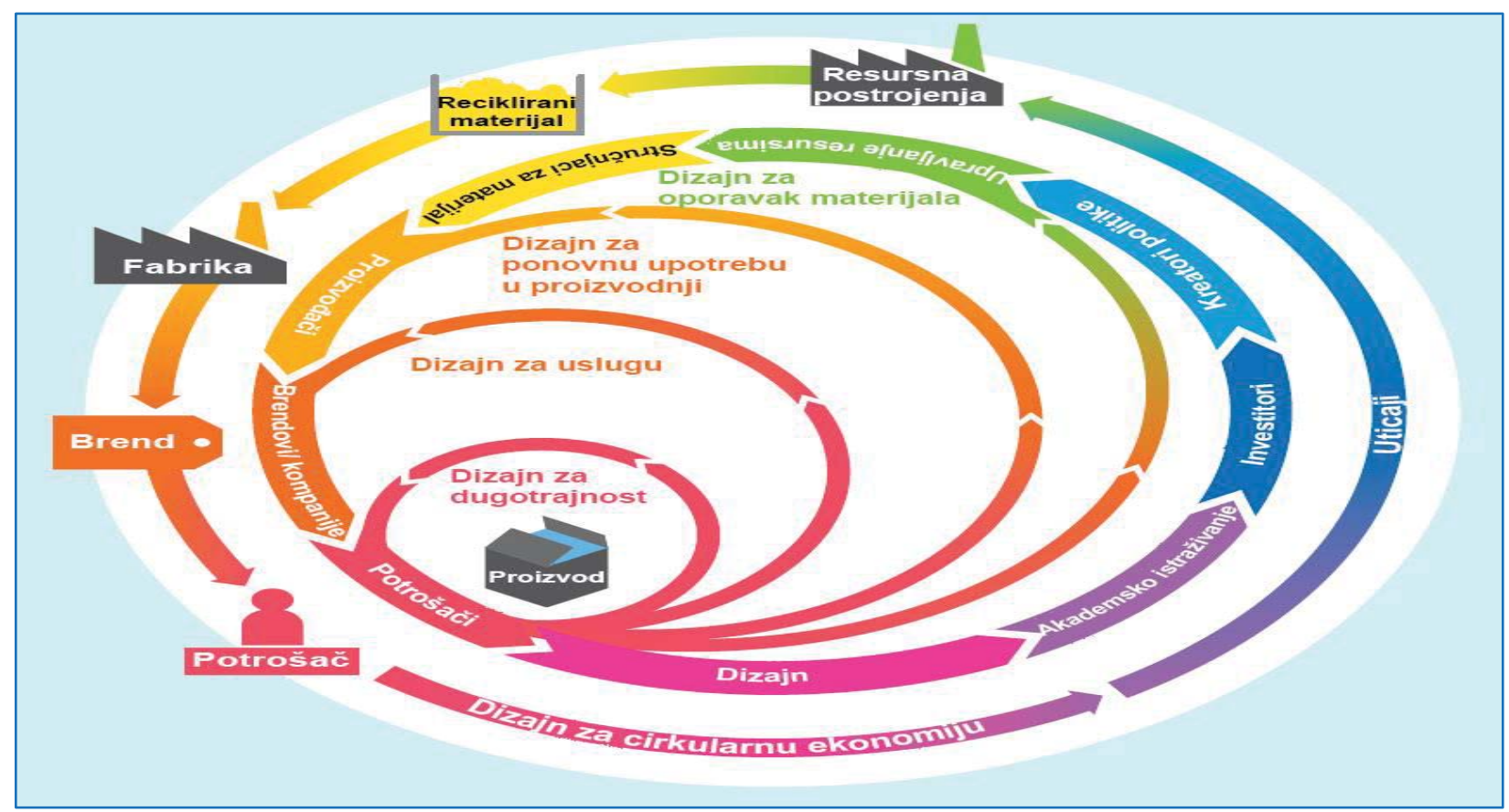

Slika 1 - Dizajn u cirkularnoj ekonomiji - model od četiri nivoa

Figure 1 - Design in a circular economy - a four-level model Izvor / Source: (RSA, 2016)

Republika Srbija prva je iz regiona zemalja zapadnog Balkana koja je izradila inicijalni dokument „Mapa puta za cirkularnu ekonomiju“. Ovaj strateški dokument predstavlja putokaz ka tranziciji na model cirkularne ekonomije, koji pored profita u fokus stavlja i zaštitu životne sredine i očuvanje resursa. Cilj Mape puta je da primenom cirkularnog modela ekonomska, društvena i ekološka dimenzija dobiju podjednaku vrednost. Republika Srbija na putu ka članstvu u Evropskoj uniji, nastoji da se u narednom periodu uskladi sa njihovim preporukama, i u skladu sa tim sprovede niz aktivnosti, koje podrazumevaju i izradu Mape puta 2.0 za cirkularnu ekonomiju (Ministarstvo zaštite životne sredine, 2020). Sve navedeno doprinelo bi da Republika Srbija dobije novu tržišnu poziciju.

U eri koju je obeležila permanentna promena trendova, previše je lako pretpostaviti da modna i tekstilna industrija u nekim evropskim zemljama, predstavljaju vrlo bitan deo privrede, dok u Republici Srbiji pretenduje da postane takav. Industrije tekstila, odeće, kože i obuće predstavljaju važne proizvodne grane Republike Srbije, sa utemeljenom praksom uvozne zavisnosti i izvozne orijentisanosti ka evrop- skom i svetskom tržištu. Prema podacima Privredne komore Republike Srbije ova delatnost obavlja se u oko 2.000 firmi (Privredna komora Srbije, 2020). Raspoloživi podaci iz 2018. godine za, čitavu teritoriju Republike Srbije, ukazuju da je uvezena neto masa tekstila iznosila 63.299,3 tona u formi vlakana, pređe, tkanina, pletenina i netkanog tekstilnog materijala, što predstavlja $0,33 \%$ od mase ukupno uvezenog tekstila i odeće. Polazeći od ove neto mase (63.299.3 tona), a imajući u vidu da tokom proizvodnje standardno otpadne između 10-15\% materijala, procena je da se u Republici Srbiji 2018. godine generisalo između 6.000-9.500 tona post-industrijskog tekstilnog otpada (Radetić, 2019).

Pandemija COVID-19 prouzrokovala je egzistencijalnu krizu u modnoj industriji, od proizvodnje do potrošnje. U martu 2020. godine prodaja odevnih predmeta doživela je značajan pad od čak $34 \%$ (Makintoš, 2020). Kriza nije zaobišla ni industrijsku proizvodnju u Republici Srbiji, koja je odmah pala za $17 \%$ u aprilu 2020. u odnosu na isti period 2019. godine. Najveći uticaj na međugodišnje smanjenje bio je na industrijsku proizvodnju motornih vozila (84\%), nameštaja (54\%), tekstila $(62 \%)$ i odevnih 
predmeta (46\%) (Republički zavod za statistiku, 2020). Uzevši u obzir da su se tokom pandemije na udaru među prvim industrijama našle tekstilna i odevna, može se reći da će se oporavak ovih sektora ubuduće još više gledati kroz održivu prizmu.

U okviru projekta „Platforma cikrularne ekonomije za održivi razvoj u Republici Srbiji” prikupljene su preoporuke predstavnika privatnog sektora za prevazilaženje ograničenja na putu tranzicije tekstilne industrije ka cirkularnoj ekonomiji, a one su:

- $\quad$ unapređenje infrastrukture i razvoj mreže za sakupljanje tekstilnog otpada na teritoriji Republike Srbije,

unapređenje Zakona o upravljanju otpadom u delu koji se odnosi na otpad od tekstila i regulisanje ciljeva i način monitoringa ovog toka otpada kroz podzakonska akta, i

- bolje planiranje proizvodnje, bez nagomilavanja robe i spaljivanja neprodatih artikala (Ministarstvo zaštite životne sredine, 2020).

\section{ULOGA POTROŠAČA U TRANZICIJI KA CIRKULARNOJ MODNOJ INDUSTRIJI / \\ THE ROLE OF CONSUMERS IN THE TRANSITION TO THE CIRCULAR FASHION INDUSTRY}

Tranzicija od linearne ka cirkularnoj modnoj industriji zahteva snažnu posvećenost potrošača, upravo zato što su odevni predmeti jedni od najtraženijih proizvoda široke potrošnje. Potrošački trend brze mode permanentno podstiče želju za kupovinom, ali i stvara velike količine tekstilnog otpada. Potrošači su tokom godina sveprisutne potrošačke prakse, shvatili da njihovo ponašanje može direktno da utiče na narušavanje ekološke, ekonomske i moralne ravnoteže. U skladu sa tim, potrošači preuzimaju krucijalnu ulogu u tranziciji ka cirkularnoj modnoj industriji, jer brzina i uspeh neophodnih promena značajno će zavisiti od njihovih stavova i ponašanja prema potrošnji (Koszewska et al., 2020, 327).

Istraživanje korporativnih predstavnika u preko 100 evropskih firmi pokazuje da su potrošači često pogođeni dezinformacijama ili nedostatkom informacija. Ipak, kako je rasla svest kod potrošača, tako je rasla i njihova potraga za informacijama, u prilog čemu ide i podatak da je internet pretraga za „održivom modom" utrostručena u periodu od 2016. do 2019. godine (George, 2019). Usled povećane transparentnosti uticaja modne industrije, sve veći broj potrošača postaje svestan negativnih ekološklih opterećenja koje stvara proizvodnja, potrošnja i odlaganje odevnih predmeta. U skladu sa tim potrošači prilikom kupovine postaju svesni svojih prekomerenih potrošačkih navika, koje je zarad održivosti neophodno prilagoditi ekološkim standardima. Uloga potrošača u ovoj transformaciji ključna je nakon kupovine, odnosno, donošenja odluke da li će iznošenu stvar pokloniti (tako da nastavi svoj životni vek), reciklirati, ili jednostavno baciti i uništiti na deponijama.

Modna industrija razvija mehanizme zasnovane na ideji reciklaže u kombinaciji sa ponovnom upotrebom odevnih predmeta, pri čemu je osnova njihovog funkcionisanja u podsticanju potrošača da iznošene komade odlažu u maloprodajnim objektima ekološki orjentisanog brendova (Grębosz-Krawczyk \& Siuda, 2019). Slika 2 prikazuje dizajn sistema za povrat iznošenih odevnih predmeta. Početna tačka na ovoj slici je potrošač koji odlaže iznošene odevne predmete i time ostvaruje određeni popust na narednu kupovinu. Prikupljeni materijal se dalje transportuje do postrojenja za sortiranje, gde se odlučuje o njegovoj ponovnoj upotrebi ili reciklaži. Odevni predmeti koji se mogu ponovo upotrebiti, potrebno je da izgledaju dobro i da nisu oštećeni, i kao takvi dalje se preusmeravaju na prodaju u okviru prodavnica polovne odeće po niskim cenama, ili se prosleđuju u dobrotvorne svrhe onima kojima su potrebni. Odluka o recikliranju podrazumeva dalji put kojim će materijal ići, a to je zatvoreni ili otvoreni proces recikliranja. Recikliranje u okviru zatvorenog procesa podrazumeva da se procesi odvijaju unutar industrije tekstila, odeće i obuće, tako da se reciklirana vlakna mogu koristiti u proizvodnji novih odevnih predmeta. Naspram toga, otvoreni proces recikliranja podrazumeva da se otpadni materijal više ne može pretvarati u vlakna za proizvodnju odevnih predmeta, već može poslužiti kao input za razne druge industrije. Većina takvih vlakana se prerađuje u izolacioni materijal za automobilsku ili građevinsku industriju (http://www.ico-spirit.com/en /services/).

Primer dobre prakse navedenog sistema povrata iznošenih odevnih predmeta je kompanija „H\&M“. Navedena kompanija, kao jedna od vodećih brendova brze mode, svojim pristupom u poslovanju učinila je da Republika Srbija postane deo globalne ekološke akcije. Akcija koja se sprovodi podrazumeva da kupci u maloprodajne „H\&M“ objekte mogu da donesu odevne predmete koje više ne žele da nose, a zauzvrat dobiju vaučer od $15 \%$ popusta. Ovakvim pristupom u poslovanju kompanija „H\&M“ je u 2019. godini skupila 29.005 tona tekstila namenjenog ponovnoj upotrebi ili reciklaži, što odgovara oko 145 miliona majica. Pored toga, 0,02 evra od svakog sakupljenog kilograma odevnih predmeta ova kompanija donira lokalnoj humanitarnoj organizaciji zemlje u okviru koje obavlja poslovanje. Misija kompanije je da do 2030. godine u svom poslovanju koristi samo reciklirane ili druge održive materijale (H\&M Group, 2020). 


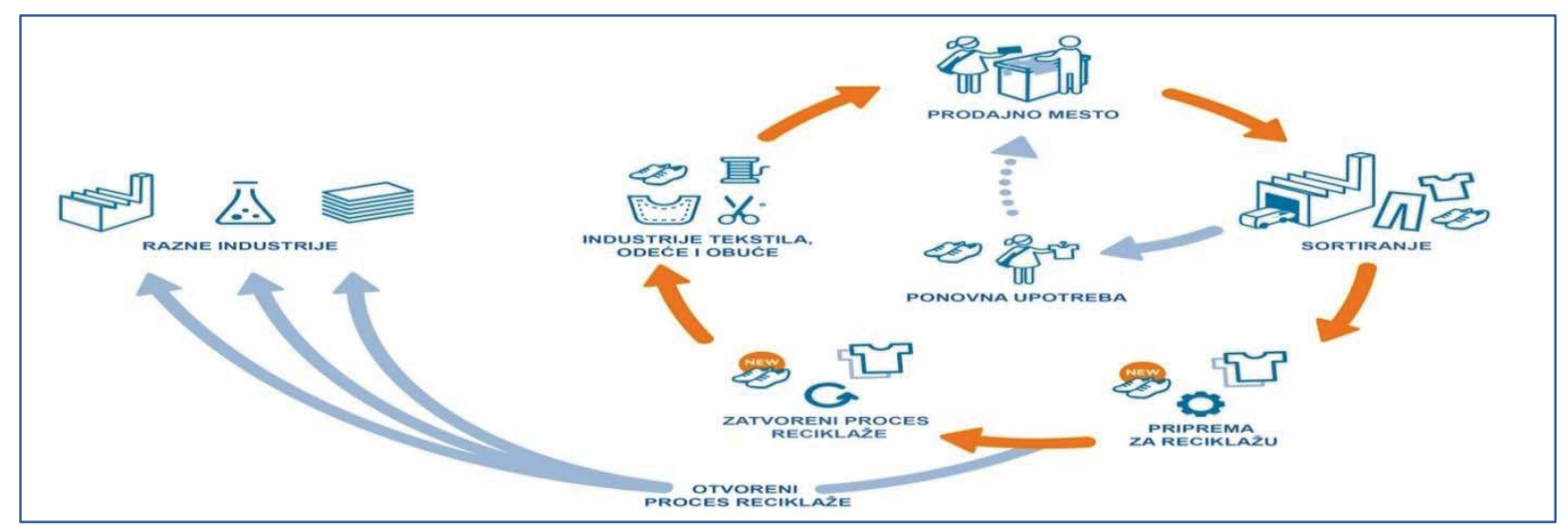

Slika 2. Dizajn sistema za povrat iznošenih odevnih predmeta

Figure 2. Design of a system for the disposal of worn-out garments Izvor / Source: http://www.ico-spirit.com/en/services/

Ekološki orjentisani brendovi primenom modela povrata iznošenih odevnih predmeta imaju sposobnost da utiču na kreiranje stabilnog i održivog modnog sektora. Planing (2015) ističe da u primeni ovog poslovnog modela potrošači igraju presudnu ulogu u tranziciji ka cirkularnoj ekonomiji. Gledano iz perspektive brenda, angažovanje i zalaganje potrošača izuzetno je važno, iz razloga što cirkularni poslovni modeli zavise od potrošačevog povrata iznošenih odevnih predmeta, koje bi kompanije mogle ponovo upotrebiti i reciklirati (Kant Hvass \& Pedersen, 2019, 359). Kant Hvass i Pedersen dalje navode, da sprovođenje modela povrata zahteva novi pristup upravljanja odnosima sa potrošačima, stoga što kompanije svoje potrošače treba da vide i kao dobavljače. Primenom navedenog cirkularnog modela vrši se podsticanje potrošača na stvaranje svesti o održivosti modnog sektora, što ujedno predstavlja njegov odgovor na izazov održivosti. Dakle, bez potrošača koji preispituju modne navike konzumiranja, a zatim i promene ponašanja i stavova prema ekološki orjentisanim brendovima, trend razvoja brze mode biće sve dramatičniji (Piribauer \& Bartl, 2019).

\section{REZULTATI I DISKUSIJA / RESULTS AND DISCUSSION}

Kupovinu kod potrošača inicira njihova želja, ali ne i potreba, da budu u trendu i da imaju ekskluzivan odevni predmet. Moda sa sve kraćim životnim ciklusima čini nerazdvojan deo potrošačkog društva, i kao takva odgovorna je za stvaranje prisile da se kupuje u što većoj meri (Maširević, 2014). U realizaciji ciljeva održivog razvoja modne industrije jednu od najvećih prepreka čini međusobno preplitanje fenomena mode i potrošnje. S obzirom na to da moda utiče na odnos potrošača prema odevnim predmetima, od suštinskog značaja je istraživanje sprovedeno od strane Centara za unapređenje životne sredine. Istraživanje o životnom ciklusu odevnih predmeta u
Republici Srbiji sprovedeno je u julu i avgustu 2020. godine metodom onlajn anketiranja, na reprezentativnom uzorku od 1889 ispitanika. Navedeno istraživanje, prvo je zvanično društveno istraživanje, koje za cilj ima da istakne koliko su građani informisani o brzoj i sporoj modi, kao i kakve su njihove potrošačke navike.

Upućenost ispitanika u fenomen brze i spore mode ukazuje da je više od polovine ispitanika $(55,3 \%)$ upoznato sa brzom modom, a $44,3 \%$ ispitanika upoznato sa sporom modom. Uvidom u nalaz ispitanika razgraničen po polu uočava se da su ispitanice za desetak procenata više upoznate sa fenomenima brze i spore mode, nego što su to ispitanici. Svest ispitanika o štetnim implikacijama brze mode postoji. Nešto manje od polovine ispitanika upoznato je sa nepovoljnim uslovima u kojima se proizvodi odeća, dok svaki treći ispitanik ima uvid u energetsku rasipnost modne industrije. Ukoliko se u obzir uzme upućenost ispitanika u brzu modu od $55,3 \%$, uviđa se da dolazi do procentualnog pada upućenosti ispitanika kada se radi o konkretnim ishodima i posledicama brze mode. Shodno prethodnom, uzevši u obzir sociodemografske pokazatelje, stariji ispitanici, ispitanici višeg stepena obrazovanja, kao $i$ ispitanici koji pripadaju donjoj klasi, znatno su više upućeni u štetne posledice ove industrije.

Prilikom procene potrošačkih prioriteta u kupovini, kvalitetom se prevashodno rukovodi $54,5 \%$ ispitanika, cena je presudna za $41,2 \%$ ispitanika, dok svaki dvadeseti ispitanik $(4,3 \%)$ navodi da je pri kupovini najvažnije da je modni proizvod u trendu. Da je ispitanicima zaista bitan kvalitet proizvoda potvrđuje nalaz da prilikom kupovine čak $71,8 \%$ njih obraća pažnju na sirovinski sastav, a za $70,5 \%$ njih nije važno u kojoj zemlji je proizvod proizveden.

Prilikom ispitivanja potrošačke prakse ispitanika kao vremenski okvir uzet je jednogodišnji ciklus. 
Shodno tome, 1889 ispitanika, za godinu dana, zbirno je kupilo odevnih predmeta u težini većoj od 22 tone. $U$ proseku, za godinu dana svaki ispitanik kupio je odeću u težini od 11,73 kilograma. Ukoliko se uzme u obzir reprezentativnost uzorka, ekstrapoliranjem dobijenog nalaza na populaciju Republike Srbije (prema Republičkom zavodu za statistiku u 2019. godini procenjen broj stanovnika je 6.945.235) težina kupljene odeće na godišnjem nivou dostiže $81.467,6$ tona.

U Tabeli 1. precizno se može videti gde ispitanici po osnovu godišta, obrazovanja i klasne samoper- cepcije najčešće nabavljaju odeću, kao i koje se kategorije unutar njih najviše ističu po svojim preferencijama. Kupovinu odeće preko $60 \%$ ispitanika nabavlja u prodavnicama globalnih brendova, više od $16 \%$ u prodavnicama polovne odeće, a nešto manji broj njih $(13,4 \%)$ preferira kupovinu u radnjama domaćih proizvođača. Razgraničenje prema polu ispitanika, ukazuje da muškarci radije kupuju u prodavnicama globalnih brendova, dok žene više koriste prodavnice polovne odeće.

Tabela 1 - Gde najčešće ispitanici kupuju odeću?

Table 1 - Where do respondents most often buy clothes?

\begin{tabular}{|c|c|c|c|c|c|c|c|c|c|c|c|c|c|c|}
\hline \multirow[b]{2}{*}{$\begin{array}{c}\text { Gde najćešće } \\
\text { kupujete } \\
\text { proizvode? } \\
\text { (procenti) }\end{array}$} & \multicolumn{3}{|c|}{ GODIŠTE } & \multicolumn{6}{|c|}{ OBRAZOVANJE } & \multicolumn{5}{|c|}{ KLASNA SAMOPERCEPCIJA } \\
\hline & $\begin{array}{l}\text { ஜ్ } \\
\infty \\
\infty\end{array}$ & $\frac{\stackrel{f}{f}}{\frac{1}{m}}$ & $\frac{\substack{0 \\
: \infty}}{\geq}$ & $\begin{array}{l}\frac{\pi}{2} \\
\sum_{0}^{0} \\
\text { Oొ }\end{array}$ & 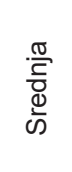 & $\underbrace{>}_{\substack{0 \\
: 00}}$ & 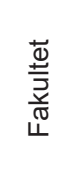 & 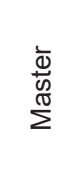 & $\begin{array}{l}\frac{\pi}{0} \\
\frac{\pi}{0} \\
\frac{1}{0} \\
0\end{array}$ & $\begin{array}{l}\frac{\pi}{\overparen{Z}} \\
\frac{0}{0} \\
0\end{array}$ & 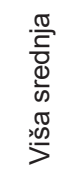 & $\begin{array}{l}\frac{\pi}{2} \\
\frac{0}{0} \\
\frac{d}{\omega} \\
\mathbb{N} \\
\frac{N}{Z} \\
\frac{N}{Z}\end{array}$ & . & 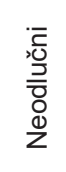 \\
\hline $\begin{array}{l}\text { Prodavnice } \\
\text { domaćih } \\
\text { proizvođača }\end{array}$ & 13,7 & 15,8 & 13,9 & 18,9 & 14,7 & 13,9 & 13,1 & 12,8 & 25,0 & 5,9 & 11,5 & 15,8 & 17,1 & 16,3 \\
\hline $\begin{array}{l}\text { Prodavnice } \\
\text { globalnih } \\
\text { brendova }\end{array}$ & 62,9 & 57,3 & 51,4 & 54,1 & 62,7 & 59,4 & 63,1 & 56,3 & 62,5 & 94,1 & 67,9 & 55,6 & 48,8 & 62,0 \\
\hline $\begin{array}{c}\text { Prodavnice } \\
\text { polovne odeće }\end{array}$ & 16,0 & 16,5 & 18,1 & 18.9 & 15,7 & 17.6 & 15,2 & 18,4 & 9,4 & l & 12,2 & 19,9 & 26,8 & 13,6 \\
\hline $\begin{array}{c}\text { Online } \\
\text { kupovina }\end{array}$ & 1,3 & 2,4 & 4,2 & I & 1,6 & l & 1,4 & 2,5 & l & l & 1,8 & 1,5 & 2,4 & 1,8 \\
\hline Na pijaci & 0,6 & 0,5 & 1,4 & 8,1 & 0,5 & 1,6 & 0,2 & 1,3 & 1 & 1 & 0,4 & 0,9 & 1 & 0,5 \\
\hline Negde drugde & 5,5 & 7,5 & 11,0 & 1 & 4,8 & 7,5 & 7,0 & 8,7 & 3,1 & 1 & 6,2 & 6,3 & 4,9 & 5,8 \\
\hline Total & 100 & 100 & 100 & 100 & 100 & 100 & 100 & 100 & 100 & 100 & 100 & 100 & 100 & 100 \\
\hline
\end{tabular}

Izvor / Source: (Pavlica, 2020)

Diferenciranje potrošačkih navika postoji kada se u obzir uzmu sociodemografski pokazatelji. Posmatrano kroz polnu distribuciju uočava se da krupnijih odstupanja nema, te da ona postoje samo kod odeće koja je polno predodređena. Potrošačka praksa sagledana kroz generacijsku prizmu, ukazuje na postojanje blage tendencije da mlađi ispitanici kupuju u proseku više, nego što to čine stariji ispitanici. Primetan uticaj na potrošačke navike ima nivo obrazovanja, tako da ispitanici sa najvišim stepenom obrazovanja (doktoratom) beleže veće prosečne potrošačke skorove. Deklarisanje ispitanika kao pripadnika gornje klase, preklapa se sa njihovom potrošačkom praksom, zahvaljujući kojoj prednjače sa prosečnim kupovnim balansima. Stoga, dok su ispitanici gornje klase u proseku kupili devet i po majica, ispitanici donje klase kupili su tri i po ista takva odevna predmeta.

Dužina nošenja odeće u zbirnom proseku svih tipova odevnih predmeta iznosi otprilike 37 meseci. Imajući u vidu da je za proizvodnju jedne majice potrebno 2700 litara vode, a za proizvodnju jednog para farmerki 10.000 litara vode (Vejin, 2020), zabrinjava- jući podatak je da skoro svaki treći ispitanik nosi pantalone ili farmerke, trenerke i majice do godinu dana. Istraživanje sagledano iz polne perspektive, ruši stereotipe da žene prednjače u kupovini, te je tako period nošenja odevnih predmeta kraći kod muškaraca nego kod žena.

Odlaganje iznošene odeće nalazi se na kraju potrošačkog ciklusa. Diferenciranje potrošačke prakse unutar sociodemografskih kategorija prikazano je u Tabeli 2. Naime, nešto više od polovine $(55 \%)$ ispitanika poklanja odeću. Isti procenat, oko $16 \%$ ispitanika čuva iznošenu odeću u ormaru i donira je. Neuporedivo manji broj ispitanika 3,7\% ima sklonost ka bacanju iznošene odeće, dok najmanji procenat ispitanika $2,2 \%$ nastoji da takvu odeću proda. Uvidom u dobijene podatke možemo reći da više od polovine anketiranih ispitanika u Republici Srbiji pokazuje zavidan nivo kulture prilikom odlaganja iznošenih odevnih predmeta. Stoga što istraživanja pokazuju da ponovna upotreba odevnih predmeta ima veću ekološku korist od recikliranja (Watson et al., 2015). 
Tabela 2 - Odlaganje iznošene odeće / Table 2 - Disposal of worn-out clothes

\begin{tabular}{|c|c|c|c|c|c|c|c|c|c|c|c|c|c|c|c|c|}
\hline \multirow{2}{*}{$\begin{array}{c}\text { Šta } \\
\text { najčešće } \\
\text { radite sa } \\
\text { odećom } \\
\text { koju više } \\
\text { ne } \\
\text { nosite? } \\
\text { (procenti) }\end{array}$} & \multicolumn{2}{|c|}{$\mathrm{POL}$} & \multicolumn{3}{|c|}{ GODIŠTE } & \multicolumn{6}{|c|}{ OBRAZOVANJE } & \multicolumn{5}{|c|}{ KLASNA SAMOPERCEPCIJA } \\
\hline & 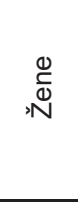 & 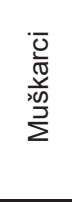 & 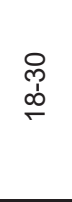 & $\frac{\stackrel{f}{+}}{\stackrel{n}{m}}$ & 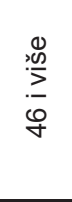 & $\begin{array}{l}\frac{\pi}{2} \\
\frac{0}{\delta} \\
\frac{5}{n} \\
0\end{array}$ & $\begin{array}{l}\frac{\pi}{\bar{T}} \\
\frac{\overline{0}}{0} \\
\dot{\omega} \\
\dot{\omega}\end{array}$ & 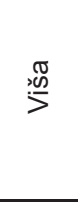 & 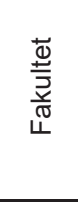 & 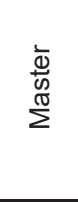 & $\begin{array}{l}\text { त्र } \\
\overline{0} \\
\frac{0}{0} \\
0\end{array}$ & : & 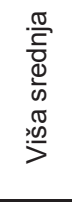 & $\begin{array}{l}\frac{\mathbb{N}}{\bar{c}} \\
\frac{0}{0} \\
\frac{d}{\omega} \\
\mathbb{N} \\
\frac{N}{Z}\end{array}$ & $\frac{.0}{\frac{\pi}{D}}$ & 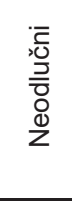 \\
\hline $\begin{array}{l}\text { Čuvam je } \\
\text { u ormaru }\end{array}$ & 15,3 & 23,7 & 17,2 & 13,1 & 8,3 & 16,2 & 18,7 & 15,0 & 14,5 & 11,9 & 6,3 & 1 & 13,7 & 18,6 & 7,3 & 14,9 \\
\hline Bacam je & 3,7 & 3,3 & 3,9 & 3,3 & 1,4 & 2,7 & 5,2 & 4,3 & 2,3 & 0,6 & 9,4 & 1 & 1,8 & 4,4 & 14,6 & 5,0 \\
\hline $\begin{array}{c}\text { Doniram } \\
\text { je }\end{array}$ & 16,5 & 9,2 & 14,7 & 18,6 & 23,6 & 13,5 & 13,1 & 10,7 & 20,1 & 21,6 & 12,5 & 23,5 & 17,8 & 14,4 & 19,5 & 14,9 \\
\hline $\begin{array}{c}\text { Poklanjam } \\
\text { je }\end{array}$ & 55,3 & 53,9 & 55,8 & 52,3 & 59,7 & 62,2 & 56,6 & 64,2 & 49,3 & 52,2 & 65,5 & 64,7 & 57,0 & 52,7 & 48,8 & 59,7 \\
\hline $\begin{array}{c}\text { Prodajem } \\
\text { je }\end{array}$ & 2,2 & 1,3 & 2,2 & 2,4 & 1 & 1 & 2,2 & 0,5 & 3,6 & 1,6 & 1 & 5,9 & 2,4 & 2,1 & 2,4 & 1,4 \\
\hline $\begin{array}{l}\text { Nešto } \\
\text { drugo }\end{array}$ & 7,0 & 8,6 & 6,2 & 10,3 & 7,0 & 5,4 & 4,2 & 5,3 & 10,2 & 12,1 & 6,2 & 5,9 & 7,3 & 7,8 & 7,4 & 4,1 \\
\hline Total & 100 & 100 & 100 & 100 & 100 & 100 & 100 & 100 & 100 & 100 & 100 & 100 & 100 & 100 & 100 & 100 \\
\hline
\end{tabular}

S obzirom da se istraživanje odvijalo u doba pandemije COVID-19, nalazi pokazuju da su ispitanici u proseku za čak $48 \%$ smanjili kupovinu. Smanjenje kupovine najzapaženije je kod starijih ispitanika, koji su poslednjih meseci za više od $76 \%$ smanjili svoju kupovinu. Naime, pandemija COVID-19 najviše je uticala na potrošačku praksu ispitanika sa osnovnom školom i donje klase, koji su morali da se odreknu dotadašnjih navika u kupovini. Uticaj pandemije COVID-19 nije zaobišao ni potrošačku praksu gornje klase, gde je nešto više od $35 \%$ ispitanika smanjilo kupovinu odeće za više od 76\% (Pavlica, 2020).

Ukoliko napred navedene indikativne podatke uzmemo u obzir shvatamo da modna industrija vrši veliki pritisak na potrošače, u smislu stvaranja potrošačke prakse koja prati brzu smenu modnih trendova. Kao i da takav pritisak modne industrije slabi pod udarom pandemije COVID-19, što rezultira značajnim smanjenjem kupovine kod potrošača najnižih i najviših klasnih kategorija. Gazzola i dr. autori navode da usled porasta ekonomske nesigurnosti i političke nestabilnosti opada nivo potrošnje modnih proizvoda. Istovremeno, ovi autori, očekuju da će u narednim godinama rasti potražnja za prilagođenim i personalizovanim modnim predmetima, po nižoj ceni (Gazzola et al., 2020).

\section{ZAKLJUČAK / CONCLUSION}

Pod pritiskom neprekidnog smenjivanja modnih trendova globalna ekonomija izuzetno rasipa resurse, troši energiju i zagađuje životnu sredinu. Postojeći sistem u modnoj industriji, uspostavljen decenijama unazad sve više zahteva reformisanje. Tokom poslednjih nekoliko godina prepoznat je značaj tranzicije linearne ka cirkularnoj modnoj industriji, a sve sa ci- ljem da se resursno intenzivna potrošnja stavi u okvire održivosti.

Cirkularna modna industrija može postati održiva samo ukoliko postoje dobro razrađeni poslovni modeli za povrat iznošenih odevnih predmeta, a zatim i sistemi sortiranja koji će opredeliti dalji tok materijala (ponovna upotreba ili reciklaža). Izazovi u oblastima digitalizacije i održivosti modne industrije postaju sve složeniji, što uslovljava ovaj sektor da se neprekidno nadograđuje. Stoga, neophodno je da inovativna tehnologija omogući recikliranje raznih vlakana u visokokvalitetna vlakna, koje je tržište spremno da upotrebi za stvaranje novih odevnih predmeta.

Ekološki orjentisani brendovi, primenom sistema povrata odevnih predmeta, čine modni sistem boljim i održivijim, jer je njihova odgovornost orjentisana prema transparentnom boljitku životne sredine i budućnosti čitavog društva. lako se čini da je to skromni pomak ka cirkularnom modelu poslovanja, takav pristup globalnih brendova zapravo ističe krucijalnu ulogu potrošača u modnoj industriji. Osim što ovakav sistem utiče na smanjenje nekontrolisanog stvaranje otpada, on inicira da i ostali brendovi, zarad opstanka, postanu deo cirkularne ekonomije.

Pitanja održivog razvoja modne industrije postaju sve značajnija u doba pandemije izazvane virusom COVID-19. Opstanak modne industrije predstavlja veliki izazov za ovaj sektor, budući da su ukupni prihodi, usled smanjene potrošnje, veoma ugroženi. Iznalaženje iz ove situacije moguće je primenom evropskog i nacionalnog postulata, u smislu pravične raspodele resursa i očuvanja životne sredine. Dakle, cirkularni model poslovanja kao fenomen u nastajanju, ima naznaka da u budućnosti u potpunosti transformiše modni sistem. Takav sistem podrazu- 
mevaće održivost koja mora biti inkluzivna u svakom segmentu, uključujući proizvodnju, potrošnju i odlaganje odevnih predmeta.

\section{LITERATURA / REFERENCES}

[1] Baker-Brown, D. (2017), Resource matters. In: Baker-Brown, D. (Ed.), The re-use atlas, London, Riba, 7-15.

[2] Ellen McArthur Foundation. (2017). A new textiles economy: Redesigning fashion's future. Dostupno na: https://www.ellenmacarthurfoundation.org/ assets/downloads/publications/A-New-TextilesEconomy_Full-Report_Updated_1-12-17.pdf

[3] Fletcher, K. (2014). Sustainable fashion and textiles: design journeys, Il ed., Routledge, New York.

[4] Gam, H. J., Cao, H., Farr, C., Kang, M. (2010). Quest for the eco-apparel market: a study of mothers' willingness to purchase organic cotton clothing for their children, International Journal of Consumer Studies, 34 (6), 648-656.

[5] Gazzola, P., Pavione, E., Pezzetti, R., Grechi, D. (2020). Trends in the Fashion Industry, The Perception of Sustainability and Circular Economy: A Gender/Generation Quantitative Approach, Sustainability, 12 (2809), 2-19.

[6] George, S. (2019). European CEOs: Changing consumer behaviours is the next sustainability frontier, edie, 9th October 2019. Dostupno na: https://www.edie.net/news/7/European-CEOs-Changing-consumer-behaviours-is-the-nextsustainability-frontier/

[7] GFA and BCG, (2017). Pulse of the fashion industry, Global Fashion Agenda and Boston Consulting Group, Copenhagen.

[8] Grębosz-Krawczyk, M., Siuda, D. (2019). Attitudes of young European consumers toward recycling campaigns of textile companies, Autex Research Journal, 19 (4), 394-399.

[9] Hiller Connell, K., Y., Kozar, J., M. (2012). Sustainability knowledge and behaviors of apparel and textile undergraduates, International Journal of Sustainability in Higher Education, 13(4), 394-407.

[10] H\&M Group. (2020). Recycling and Upcycling. Dostupno na: https://hmgroup.com/sustainability /circular-and-climate-positive/recycling/

[11] Janković, M., Jović Bogdanović, A. (2018). Zelena ekonomija i zeleni rast, Ecologica, 25(90), 221-225.

[12] Kant Hvass, K., Pedersen, E. R. G. (2019). Toward circular economy of fashion, Experiences from a brand's product take-back initiative, Journal of Fashion Marketing and Management, 23 (3), 345-365.
[13] Koszewska, M., Rahman, O., Dyczewski, B. (2020). Circular fashion - consumers' attitudes in cross-national study: Poland and Canada, Autex Research Journal, 20 (3), 327-337.

[14] Ljubojević, G., Maksimović Sekulić, M. (2018). Zaštita životne sredine kao aspekt društvene odgovornosti kompanije u procesu pridruživanja EU, Ecologica, 25 (90), 478-482.

[15] Machado, M. A. D., Almeida de S. O., Bollick L. C., Bragagnolo, G. (2019). Second-hand fashion market: consumer role in circular economy, Journal of Fashion Marketing and Management, 23 (3), 382-395.

[16] McKinsey \& Company, (2020). The State of Fashion. Dostupno na:

https://onedrive.live.com/?cid=AA42BC75AE04C A28\&id=AA42BC75AE04CA28\%21245\&parld=A A42BC75AE04CA28\%21233\&o=OneUp

[17] Makintoš, S. (2020). Korona virus: Zašto modna industrija proživljava egzistencijalnu krizu. Dostupno na: https://www.bbc.com/serbian/lat/svet52516674

[18] Maširević, Lj. (2014). Potrošačko društvo i moda, Kultura, 143, 203-218.

[19] Ministarstvo zaštite životne sredine, (2020). Sektor za strateško planiranje i projekte, Mapa puta za cirkularnu ekonomiju u Srbiji, Beograd. Dostupno na: https://cdn.agroklub.com/upload/ documents/final-202004020-roadmapsrbija.pdf?_gl=1*anot $66^{*}$ _ga*MTU5MTIzMzU0Mi 4xNjEwOTU5ODc2*_ga_YE2MMQB0RG*MTYx MDk1OTg3NS4xLjAuMTYXMDk1OTg3NS4w

[20] NCEAP, (2020). A new Circular Economy Action Plan For a cleaner and more competitive Europe. Dostupno na: https://ec.europa.eu/environment/ circular-economy/pdf/new_circular_economy_ action_plan.pdf

[21] Pavlica, D. (2020). Vreme je za novu modu, Analiza istraživanja o životnom ciklusu odevnih predmeta u Republici Srbiji, Centar za unapređenje životne sredine, Beograd. Dostupno na: file://C:/Users/hp.hp-PC/Desktop/Cirkularna\%20 ekonomija/Analiza_istrazivanja_o_zivotnom_cikl usu_odevnih_predmeta_u_RS.pdf

[22] Piribauer, B., Bartl, A. (2019). Textile recycling processes, state of the art and current developments: A mini review. Waste Manag Res, 37 (2), 111-119.

[23] Planing, P. (2015). Business model innovation in a circular economy: reasons for non-acceptance of circular business models, Open Journal of Business Model Innovation, 1-11. 
[24] Privredna komora Srbije, (2020). Bilten, Udruženje za industriju tekstila, odeće, kože i obuće, III kvartal, jul-septembar 2020. Dostupno na:

https://api.pks.rs/storage/assets/\%D0\%91\%D0\% B8\%D0\%BB\%D1\%82\%D0\%B5\%D0\%BD,\%20III \%20\%D0\%BA\%D0\%B2\%D0\%B0\%D1\%80\%D1 \%82\%D0\%B0\%D0\%BB\%202020..pdf

[25] Radetić, M. (2019). Problem tekstilog otpada u razvoju cirkularne ekonomije u Republici Srbiji, Program Ujedinjenih nacija za razvoj (UNDP), Beograd.

[26] Republički zavod za statistiku, (2020). Mesečni statistički bilten, (april 2020). Dostupno na: https:// publikacije.stat.gov.rs/G2020/Pdf/G20203007.pdf

[27] Rousso, C. (2012). Fashion Forward: A Guide to Fashion Forecasting, Fairchild Publications: London.

[28] RSA, (2016). Action and Research Centre, Designing for a circular economy: Lessons from the great recovery 2012-2016, London, UK.
[29] Svensson, V. (2016). Consumer culture: The day your baby's wardrobe became better than yours. Dostupno na:

https://www.youtube.com/watch?v=4v4Pf5Dt8Hg

[30] Vejin, T. (2020). Green fest - istraživanje životnog ciklusa odeće, Zelene priče. Dostupno na: https://zeleneprice.info/green-fest/

[31] Watson, D., Kiørboe, N., Palm, D., Tekie, H., Ekvall, T., Lindhqvist, T., Tojo, N., Salmenperä, H., Hanssen, O.J., Rubach, S., Lyng, K.-A. and Gíslason, S. (2015). EPR-Systems and New Business Models, Part II: Policy Packages to Increase Reuse and Recycling of Textiles in the Nordic Region, TemaNord and Nordisk Ministerråd, Copenhagen.

[32] http://www.ico-spirit.com/en/services/

[33] https://www.ico-spirit.com/en/ 